\title{
Quality of life after Renal Transplantation
}

\section{Ali TahaAli,Yasser Mohamed Kamal ,Asmaa El Sayed Abd El Aal Internal medicine department,.Sohag University Hospital.}

\begin{abstract}
Objective: This study was carried out with the purpose of assessment quality of life of patients who have undergone kidney transplants and factors affecting it.

Methodology: The study included 50 cases at Nephrology Outpatient Clinic at Sohag University Hospital the research was conducted at the duration from setmper 2017 to march 2018, In this study quality of life for patients after renal transplantation was assessed by two tools:

1-Quality of life questionnaire

2-Lab investigations

Results: The average scores for quality of life after renal transplantation were good ,many facors affect quality of life after renal transplantation ,in this study we discussed gender,residence, marital state,work,age duration of dialysis,duration after renal transplantation and level of serum creatinine,Study findings clarified that gender,marital state, work state and duration of dialysis had no statistically significant distinction between them and total QOL score while residence,age,duration of transplantation and level of serum creatinine after renal transplantation had statistically significant distinction between them and total QOL score.
\end{abstract}

\section{Conclusion:}

$t$ was concluded that: the average scores for quality of life after renal transplantation were good, residence, age,duration of transplantation and level of serum creatinine after renal transplantation had impact on quality of life after renal transplantation but gender,marital state,work state and duration of dialysis had no impact on quality of life after renal transplantation.

Key words: Kidney transplantation, Quality of life, Factors affecting.

\section{Introduction}

Chronic Kidney Disease (CKD) is recognized as a major health problem affecting approximately $13 \%$ of the United States population[1], According to the most recent Egyptian renal registry in 2008, the prevalence of ESRD is 483 per million populations and the total recorded number of ESRD patients on dialysis is 40000.[2]

End stage renal disease patients undergoing hemodialysis live with varying degrees of physical and psychological symptoms. Many medical problems result from ESRD lead to a reduction in physical functioning and medical complications such as anemia, cardiovascular, and neurologic complications, in addition to hemodialysis (HD) complications such as hypotension, headache, air embolism, and transmission of blood-borne infections such as hepatitis $\mathrm{C}$ virus, All these complications lead to diminished working capacity as energy level often precipitates an inability to pursue fulltime employment. The preferred treatment for end-stage renal diseases (ESRD) remains kidney transplantation, which is associated with a long-term mortality improvement over dialysis. Transplantation is less expensive than dialysis. It also helps patients enjoy a life 
filled with more freedom, energy and productivity. Although most patients are on dialysis before first being evaluated for transplantation, patients with endstage renal disease can be referred for transplantation even before starting dialysis [3], While cautious criteria for selection of living kidney donors are credited for favorable outcomes, recent practice changes may include acceptance of less than ideal donors, even obese and old one are suitable candidates with condition of being free of systemic disease or infection, have normal renal function, and be without major medical problems. Of course doctors will decide possibility of being donor after further evaluation. [4,5] Preparation is the key and specialist nurses have a pivotal role in leading and providing education and support for patients throughout the transplant process. It is an ongoing process, focusing on the delivery of consistent, comprehensive and realistic information to ensure that transplant recipients are aware of the long-term commitment to self-administration of medications, side effect profiles, surveillance and the rational for concordance with immunosuppressive regimens to optimize their health and the longevity of graft function [6]

The World Health Organization defines health related quality of life (HRQoL) as individuals' perception of their position in life in the context of the culture and value systems in which they live and in relation to their goals, expectations, stand-ards, and concerns. Health-related quality of life encompasses an individual's perception of physical and mental health, as well as his/her capacity to react to variables in the environment [7]

\section{Methodology}

A retrospective study design will be used at sohag University outpatient Nephrology clinic, Study will include about 50 cases at age between 18-35 years old and will be evulated by two tools :

Tool (I): Quality of Life questionnaire, It includes three parts:

Part (1): Demographic Data: - Includes data about the general characteristics of the study sample such as sex, age, marital status, and level of education, etc.

Part (2): Medical history, It includes questions about medical history like duration of dialysis, source of transplanted kidney, complications after transplantation, and period after transplantation.

These questions developed by the researcher and written in simple language in the form of multiple choice questions.

Part (3): KDQOL questionnaire -SF

Tool (II): Include lab investigation of serum creatinine, hemoglobin, white blood cells, and platelet for both dialysis period (obtained from archive) and transplantation period.

The study was conducted during the period from the beginning of setmper (2017) to the end of march(2018).

\section{Results}

Our study design was done at sohag University outpatient Nephrology clinic , Study included 50 cases and were evulated ,between age 18-35 year, 12 females and 38 males Table (1) showing Sociodemographic characteristics of studied populations 
SOHAG MEDICAL JOURNAL

Vol. 22 No.3 october 2018
Quality of life after Renal Transplantation Asmaa El Sayed Abd El Aal

Table 1:Sociodemographic characteristics of studied populations

\begin{tabular}{|c||c|}
\hline Variable & Summary statistics \\
\hline Age/years & $34.16 \pm 8.02$ \\
Mean \pm SD & $35(21-45)$ \\
Median (range) & $12(23.53 \%)$ \\
Gender & $38(76.47 \%)$ \\
Females & \\
Males & $40(80.39 \%)$ \\
\hline Residence & $10(19.61 \%)$ \\
Rural & \\
Urban & $17(33.33 \%)$ \\
\hline Work status & $33(66.67 \%)$ \\
\hline Not work for cash & \\
Work for cash & $15(29.41 \%)$ \\
\hline Marital status & $33(66.67 \%)$ \\
Single & $2(3.92 \%)$ \\
Married & \\
Divorced & \\
\hline
\end{tabular}

Table 2 Mean scores of scales of physical component summary of the KDQOL-SF instrument among studied populations

\begin{tabular}{|l||c||c|c|c||}
\hline Variable & Mean \pm SD & Median & Min & Max \\
\hline \hline General health & $83.36 \pm 16.63$ & 90 & 45 & 100 \\
\hline \hline Physical function & $92.35 \pm 6.95$ & 95 & 80 & 400 \\
\hline \hline Bodily pain & $87.21 \pm 20.40$ & 100 & 45 & 100 \\
\hline \hline Role physical function & $80.88 \pm 32.40$ & 100 & 0 & 100 \\
\hline \hline $\begin{array}{l}\text { Physical component } \\
\text { summary (PCS) }\end{array}$ & $85.91 \pm 16.94$ & 92.5 & 42.5 & 100 \\
\hline
\end{tabular}

Table $3_{\text {Mean scores of scales of mental component summary of the KDQOL-SF instrument }}$ among studied populations

\begin{tabular}{|l||c||c||c|c|}
\hline Variable & Mean \pm SD & Median & Min & Max \\
\hline \hline Fatigue/energy & $85.43 \pm 18.83$ & 95 & 40 & 100 \\
\hline \hline Emotional well being & $90.99 \pm 14.31$ & 100 & 40 & 100 \\
\hline \hline Role emotional & $86.60 \pm 31.33$ & 100 & 0 & 100 \\
\hline \hline Social function & $88.15 \pm 19.59$ & 100 & 33.3 & 100 \\
\hline \hline $\begin{array}{l}\text { Mental component } \\
\text { summary (MCS) }\end{array}$ & $87.79 \pm 16.47$ & 97.5 & 35.95 & 100 \\
\hline
\end{tabular}


SOHAG MEDICAL JOURNAL

Vol. 22 No.3 october 2018
Quality of life after Renal Transplantation

Asmaa El Sayed Abd El Aal

Table 4 : Mean scores of scales of kidney disease component summary of the KDQOL-SF instrument among studied populations

\begin{tabular}{|c|c|c|c|c|}
\hline Variable & Mean \pm SD & Median & Min & Max \\
\hline Symptoms problem list & $96.61 \pm 4.12$ & 497.7 & 79.54 & 100 \\
\hline Effect of kidney disease on quality life & $95.67 \pm 7.44$ & 100 & 67.85 & 100 \\
\hline Burden of kidney disease & $86.63 \pm 19.80$ & 100 & 31.25 & 100 \\
\hline Sleep & $\mathbf{9 7 . 7 2} \pm \mathbf{8 . 8 3}$ & 100 & 43.75 & 100 \\
\hline Social support & $95.41 \pm 11.13$ & 100 & 49.8 & 100 \\
\hline Work status & $66.67 \pm 42.03$ & 100 & $\mathbf{0}$ & 100 \\
\hline Satisfaction & $44.71 \pm 17.36$ & 55 & 25 & 70 \\
\hline Sexual & $94.12 \pm 20.47$ & 100 & $\mathbf{0}$ & 100 \\
\hline Encouragement & $82.35 \pm 21.96$ & 100 & 50 & 100 \\
\hline Cognitive function & $96.59 \pm 9.38$ & 100 & 53.3 & 100 \\
\hline Quality of social interest & $97.38 \pm 6.56$ & 100 & 73.3 & 100 \\
\hline $\begin{array}{l}\text { Kidney disease component summary } \\
\text { (KDS) }\end{array}$ & $86.31 \pm 8.66$ & 87.1 & 55.98 & 97.2 \\
\hline Total QOL score & $86.6 \pm 12.05$ & 92.7 & 46.47 & 98.5 \\
\hline
\end{tabular}

In our study we searched for factors affecting quality of life after renal transplantation

Table 5 Impact of gender on the three component summary of the KDQOL-SF instrument among studied populations

\begin{tabular}{|c|c|c|c|}
\hline \multirow[b]{2}{*}{ Variable } & \multicolumn{2}{|c|}{ Gender } & \multirow[b]{2}{*}{ P value } \\
\hline & $\begin{array}{c}\text { Females } \\
\mathbf{N}=12\end{array}$ & $\begin{array}{l}\text { Males } \\
\mathbf{N}=\mathbf{3 8}\end{array}$ & \\
\hline $\begin{array}{l}\text { Physical component } \\
\text { summary (PCS) } \\
\text { Mean } \pm \text { SD } \\
\text { Median (range) }\end{array}$ & $\begin{array}{c}96.7 \pm 3.76 \\
97.9(90-100)\end{array}$ & $\begin{array}{c}82.59 \pm 18.05 \\
90(42.5-98.7)\end{array}$ & 0.01 \\
\hline $\begin{array}{l}\text { Mental component } \\
\text { summary (MCS) } \\
\text { Mean } \pm \text { SD } \\
\text { Median (range) }\end{array}$ & $\begin{array}{c}89.42 \pm 12.65 \\
97.7(66.2-100)\end{array}$ & $\begin{array}{c}87.29 \pm 17.60 \\
95(35.95-100)\end{array}$ & 0.70 \\
\hline $\begin{array}{l}\text { Kidney disease component } \\
\text { summary (KDS) } \\
\text { Mean } \pm \text { SD } \\
\text { Median (range) } \\
\end{array}$ & $\begin{array}{c}82.62 \pm 9.63 \\
84.85(63.4-95.7) \\
\end{array}$ & $\begin{array}{c}87.45 \pm 8.03 \\
88.4(55.98-97.2) \\
\end{array}$ & 0.09 \\
\hline $\begin{array}{l}\text { Total QOL score } \\
\text { Mean } \pm \text { SD } \\
\text { Median (range) }\end{array}$ & $\begin{array}{c}91.05 \pm 5.24 \\
93.40(80.1-98.5)\end{array}$ & $\begin{array}{c}85.71 \pm 13.27 \\
91.5(46.47-98.2)\end{array}$ & 0.18 \\
\hline
\end{tabular}


Table 6 :Impact of residence on the three component summary of the KDQOL-SF instrument among studied populations

\begin{tabular}{|c|c|c|c|}
\hline \multirow[b]{2}{*}{ Variable } & \multicolumn{2}{|c|}{ Residence } & \multirow[b]{2}{*}{ P value } \\
\hline & $\begin{array}{l}\text { Rural } \\
\mathbf{N}=40\end{array}$ & $\begin{array}{l}\text { Urban } \\
\mathbf{N}=10\end{array}$ & \\
\hline $\begin{array}{l}\text { Physical component } \\
\text { summary (PCS) } \\
\text { Mean } \pm \text { SD } \\
\text { Median (range) } \\
\end{array}$ & $\begin{array}{c}83.96 \pm 18.33 \\
91.25(42.5-100) \\
\end{array}$ & $\begin{array}{c}93.9 \pm 3.83 \\
95(88.7-100) \\
\end{array}$ & 0.10 \\
\hline $\begin{array}{l}\text { Mental component } \\
\text { summary (MCS) } \\
\text { Mean } \pm \text { SD } \\
\text { Median (range) } \\
\end{array}$ & $\begin{array}{c}85.53 \pm 17.42 \\
92(35.95-100)\end{array}$ & $\begin{array}{c}97.04 \pm 6.32 \\
100(80-100)\end{array}$ & 0.046 \\
\hline $\begin{array}{l}\text { Kidney disease component } \\
\text { summary (KDS) } \\
\text { Mean } \pm \text { SD } \\
\text { Median (range) }\end{array}$ & $\begin{array}{c}84.98 \pm 8.71 \\
85.5(55.98-97)\end{array}$ & $\begin{array}{c}91.79 \pm 6.22 \\
95.5(81.2-97.2)\end{array}$ & 0.02 \\
\hline $\begin{array}{l}\text { Total QOL score } \\
\text { Mean } \pm \text { SD } \\
\text { Median (range) }\end{array}$ & $\begin{array}{c}85.19 \pm 12.70 \\
88.1(46.47-98.2)\end{array}$ & $\begin{array}{c}94.22 \pm 4.02 \\
95.3(85.9-98.5)\end{array}$ & 0.03 \\
\hline
\end{tabular}

Table 7 Impact of marital status on the three component summary of the KDQOL-SF instrument among studied populations

\begin{tabular}{|c|c|c|c|}
\hline \multirow[b]{2}{*}{ Variable } & \multicolumn{2}{|c|}{ Marital status } & \multirow[b]{2}{*}{ P value } \\
\hline & $\begin{array}{c}\text { Married } \\
\mathbf{N}=\mathbf{3 3}\end{array}$ & $\begin{array}{c}\text { Unmarried } \\
\mathbf{N}=17\end{array}$ & \\
\hline $\begin{array}{l}\text { Physical component } \\
\text { summary (PCS) } \\
\text { Mean } \pm \text { SD } \\
\text { Median (range) } \\
\end{array}$ & $\begin{array}{c}83.22 \pm 18.34 \\
91.88(42.5-100) \\
\end{array}$ & $\begin{array}{c}91.28 \pm 12.54 \\
94.3(47.5-100) \\
\end{array}$ & 0.11 \\
\hline $\begin{array}{l}\text { Mental component } \\
\text { summary (MCS) } \\
\text { Mean } \pm \text { SD } \\
\text { Median (range) }\end{array}$ & $\begin{array}{c}87.67 \pm 16.44 \\
97.7(50-100)\end{array}$ & $\begin{array}{c}88.02 \pm 17.02 \\
93.5(35.95-100)\end{array}$ & 0.94 \\
\hline $\begin{array}{l}\text { Kidney disease component } \\
\text { summary (KDS) } \\
\text { Mean } \pm \text { SD } \\
\text { Median (range) }\end{array}$ & $\begin{array}{c}88.08 \pm 6.58 \\
88.05(74.5-97.2)\end{array}$ & $\begin{array}{c}82.78 \pm 11.21 \\
85.5(55.98-95.7)\end{array}$ & 0.04 \\
\hline $\begin{array}{l}\text { Total QOL score } \\
\text { Mean } \pm \text { SD } \\
\text { Median (range) }\end{array}$ & $\begin{array}{c}86.024 \pm 12.33 \\
92.85(58.69-98.2) \\
\end{array}$ & $\begin{array}{c}88.40 \pm 11.69 \\
89.04(46.47-98.5)\end{array}$ & 0.55 \\
\hline
\end{tabular}

Table 8 Impact of work status on the three component summary of the KDQOL-SF instrument among studied populations

\begin{tabular}{|c|c|c|c|}
\hline \multirow[b]{2}{*}{ Variable } & \multicolumn{2}{|c|}{ Work status } & \multirow[b]{2}{*}{ P value } \\
\hline & $\begin{array}{c}\begin{array}{c}\text { Not work for cash } \\
N=17\end{array} \\
\end{array}$ & $\begin{array}{c}\begin{array}{c}\text { Work for cash } \\
\mathbf{N}=33\end{array} \\
\end{array}$ & \\
\hline \begin{tabular}{|l|} 
Physical component \\
summary (PCS) \\
Mean \pm SD \\
Median (range) \\
\end{tabular} & $\begin{array}{c}88.02 \pm 16.19 \\
96.6(47.5-100)\end{array}$ & $\begin{array}{c}84.86 \pm 17.45 \\
92.5(42.5-100)\end{array}$ & 0.54 \\
\hline \begin{tabular}{|l|} 
Mental component \\
summary (MCS) \\
Mean \pm SD \\
Median (range) \\
\end{tabular} & $\begin{array}{c}82.49 \pm 16.92 \\
80.8(35.95-100) \\
\end{array}$ & $\begin{array}{r}90.44 \pm 15.84 \\
98.3(50-100) \\
\end{array}$ & 0.11 \\
\hline \begin{tabular}{|l} 
Kidney disease component \\
summary (KDS) \\
Mean \pm SD \\
Median (range) \\
\end{tabular} & $\begin{array}{c}78.84 \pm 9.08 \\
82.29(55.98-87.3)\end{array}$ & $\begin{array}{c}90.05 \pm 5.54 \\
90.2(74.5-97.2)\end{array}$ & $<0.0001$ \\
\hline \begin{tabular}{|l|} 
Total QOL score \\
Mean \pm SD \\
Median (range) \\
\end{tabular} & $\begin{array}{c}84.13 \pm 12.43 \\
87.5(46.47-94.8)\end{array}$ & $\begin{array}{c}88.38 \pm 11.78 \\
93.6(58.69-98.5)\end{array}$ & 0.28 \\
\hline
\end{tabular}


SOHAG MEDICAL JOURNAL

Vol. 22 No.3 october 2018
Quality of life after Renal Transplantation

Asmaa El Sayed Abd El Aal

Table9 : Correlation between independent variable (age, duration of dialysis, duration of transplant, and serum creatinine after transplant) and the three component summary of the KDQOL-SFinstrument among studied populations

\begin{tabular}{|c|c|c|c|c|c|c|c|c|}
\hline \multirow{2}{*}{ Variable } & \multicolumn{2}{|c|}{ PCS } & \multicolumn{2}{|c|}{ MCS } & \multicolumn{2}{|c|}{ KDS } & \multicolumn{2}{|c|}{ Total QOL score } \\
\hline & $\mathrm{R}$ & $\mathrm{p}$ & $\mathrm{R}$ & $\mathrm{P}$ & $\mathrm{r}$ & $\mathrm{p}$ & $\mathrm{r}$ & $\mathrm{P}$ \\
\hline Age & -0.50 & 0.0002 & -0.22 & 0.11 & 0.25 & 0.07 & -0.32 & 0.02 \\
\hline $\begin{array}{c}\text { Duration of } \\
\text { dialysis }\end{array}$ & 0.16 & 0.27 & 0.14 & 0.34 & 0.08 & 0.58 & 0.14 & 0.32 \\
\hline $\begin{array}{c}\text { Duration of } \\
\text { transplant }\end{array}$ & -0.81 & $<0.0001$ & -0.71 & $<0.0001$ & -0.24 & 0.08 & -0.78 & $<0.0001$ \\
\hline Serum creatinine & -0.71 & $<<0.0001$ & -0.57 & $<0.0001$ & -0.25 & 0.08 & -0.67 & $<<0.0001$ \\
\hline
\end{tabular}

Table ${ }^{10}$ Lab investigation before and after transplant

\begin{tabular}{|l||c|c||c|}
\hline Variable & Before transplant & After transplant & P value \\
\hline \hline WBCs & & & \\
Mean \pm SD & $9.60 \pm 3.43$ & $7.95 \pm 1.86$ & 0.004 \\
Median (range) & $10(3.9-17.5)$ & $8(3.5-11.4)$ & \\
\hline \hline HBG & & & \\
Mean \pm SD & $8.0 \pm 1.20$ & $12.44 \pm 1.76$ & $<0.0001$ \\
Median (range) & $8(5.5-10.6)$ & $12.3(10-17.7)$ & \\
\hline Platelets & & & \\
Mean \pm SD & $194.25 \pm 67.82$ & $232.27 \pm 33.47$ & $<0.0001$ \\
Median (range) & $194(120-440)$ & $230(166-290)$ & \\
\hline \hline Serum creatinine & & & \\
Mean \pm SD & $12.03 \pm 3.97$ & $1.55 \pm 0.54$ & $<0.0001$ \\
Median (range) & $11(6.4-30)$ & $1.5(0.7-2.5)$ & \\
\hline
\end{tabular}

\section{Discussion}

This study was done in Sohag University at nephrology outpatient clinic for 50 cases between age 18-35 yearto evulate their quality of life after renal transplantation.

We used KDQOL-SF questionnaire which assessed three components:

1-Physical component summary score (PCS)

2-Mental component summary score (MCS)
3-Kidney disease component summary score (KDS)

,Then we assessed the total QOL score.

This questionnaire also used at studies as Fujisawa M et al 2000 [8],Ogutmen B et al 2006[9], Yildirim A et al 2006[10],Balaska A et al 2006[11] andMehtap Curcani, Mehtap Tan 2011[12], In this study we found that the general quality of life average scores of 
the patients were good (mean total QOLscore was 86.6).

Many studies such asFujisawa A et al 2000 [8],Ogutmen B et al 2006[9], Yildirim A et al 2006[10],Balaska A et al 2006[11] , and Mehtap Curcani, Mehtap Tan2011[12],theses studies also showed that quality of life of patients after kidney transplantation has increased.

The mean scores of our study were as follow:

1-The mean score for PCS was 85.9, the minimum score was 42.5 and maximum score was 100.

2-The mean score for MCS was 87.7,the minimum score was 35.9 and maximum score was 100.

3-The mean score for KDS was 86.3, the minimum score was 55.9 and maximum score was 97.2.

4-The mean total QOL score was 86.6,the minimum score was 46.4 and maximum score was 98.5.

At Mehtap Curcani, Mehtap Tan2011[12] the scores were as follow:

1-The mean score for PCS was 53.24.

2-The mean score for MCS was 66.02.

3-The mean score for KDS was 66.02.

4-The mean total QOL score was 61.07. Many factors affecting the total QOL score as gender,residence,marital state,work, age,duration of dialysis,duration of transplantation and level of serum creatinine, We discussed these factors and their impact on the three components and impact on total QOL score.

As regard the gender we found that the distinction between gender and quality of life average scores was statistically insignificant $(p>0.05)$ except at PCS females has score higher than males $(\mathrm{p}<0.05)$.

Ogutmen B et al 2006[10]determined that quality of life of male patients was higher than that of female patients also In Mehtap Curcani, Mehtap Tan2011[12],the quality of life average scores of men patients were higher than those of women patients, and the distinction between gender and quality of life average scores, except for PCS, were statistically significant $(\mathrm{p}<0.05)$, This because men are socialized differently from women, being taught to be more independent and self-controlled, Women are taught to be more emotionally expressive, dependent, and concerned with their physical appearance in order to be accepted by society.

As regard residence and its impact on the three components and impact on total QOL score, We found that there was statistically significant distinction between residence and the mean score of the three component and the mean total QOL score, Patients in urban had scores higher than in rural,this because in urban areas patients are more educated and alert with post trasmsplantation care ,treatment and follow up,also they receive more care and medical serivces than patients in rural areas.This was similar to result found in Yildirim A 2006[10], and Mehtap Curcani, Mehtap Tan2011[12], they found that quality of life score averages of the patients in rural were found higher $(p>0.05)$, Yildirim A 2006[10] this was due to increase the educational level for patients in rural then in urban , But Ogutmen B et al 2006[9], and Ustundag $\mathrm{H}$ et al 2007[13] found out that the correlation between residence and quality of life was insignificant.

According to When marital status and its impact, it was found that the marital status had no statistically significant distinction $(\mathrm{p}<0.05)$ between it and the three components and on the total score,But single patients had higher scores at PCS and MCS more than 
married patients because single patients had more energy,less worried about future and had good social support, This was similar to findings in Mehtap Curcani, Mehtap Tan[12] they found that quality of life average scores of single patients were higher than married,though the distinction between marital status and quality of life average scores, except MCS, is statistically insignificant $(p>0.05)$, This result is in accordance with the findings of similar studies ShuFen N ,Li Ic 2005[14], Acaray ,Pinar R 2004[15],Akyol A , Karadakovan A 2002[16].

As regard the work state there is no statistically significant distinction between work state and quality of life average scores $\quad(\mathrm{p}>0.05)$ except at $\operatorname{KDS}(\mathrm{P}<0.05)$.

As regard the age we found that there was statistically significant distinction between age and the average score of the quality of life $(\mathrm{p}<0.05)$ this because young patients had more physical health than old patients also had more energy and deal better with their kidney disease, Also Fujisaw M et al 2000[8], Balaska A et al 2006[11] and Chisholm MA et al 2007[18]state that the quality of life scores of young patients who had undergone kidney transplants were higher than those of older patients, At Mehtap Curcani, Mehtap Tan2011[12]there was no statistically significant distinction between age and the average score of the quality of life. There are a number of studies indicating that there was a negative correlation between age and quality of life Yildirim A 2006[11], Poton P et al 2001[17], Chisholm MA et al 2007[18].

According to study findings it was revealed that there was statistically significant distinction between the post transplantation period and the average score $(\mathrm{p}<0.05)$, We found that patients with more post transplantation period had lower scores than patients with less post transplantation period although risk of rejection is more at the first year after transplantation. This is because of the complications of the immunosuppressive drugs which increase the incidence of infections and other co-morbiditidies and also some cases with increasing the post transplantation period their kidneys begin to be medically diseased this affect the quality. In Mehtap Curcani, Mehtap Tan 2011[12], there was no significant distinction between quality of life average scores and the post transplantation period, except for PCS ( $p>0.05$ ), it was also found that the quality of life average scores were lowest the post transplantation period of at least one year of patients, In their studiesChisholm MA et al 2007[18] chen WC et al 2007[19] ozsaker E,Ozbayir T 2005[20] determined that the post transplantation period didn't affect the patient's quality of life.

As regard the level of serum creatinine and its impact on the average scores we found that there was statistically significant distinction between the level of serum creatinine and the average scores, Patients with low serum creatinine level had higher scores than patients with rising serum creatinine $(\mathrm{p}<0.05)$.

As regard to lab investigation in this study, there was a remarkable improvement in serum creatinine and complete blood picture after transplantation but this improvement decreases with more post transplantation period, This also found at Mohamed A etal 2014[21], This finding is not in consistent with OHC.K etal 2008[22] ,they found many cases with elevated creatinine level after transplantation they 
interpreted that as an increase in creatinine level along after transplantation may be caused by a number of processes, but common causes are: Rejection, infection (e.g. urine, CMV), Tacrolimus/Cyclosporine toxicity and Altered fluid balance. Hemoglobin level and platelets count increased after transplantation as in at Mohamed A etal 2014[21], But white blood cells count decreased after transplantation,this finding is in consistent with Hurst F.P et al 2011[23] who clarified that "neutropenia is common after transplantation and caused by immunosuppressant", This not similar to findings at Mohamed A etal 2014[21]in which there is some extent increase in WBCs count after transplantation than dialysis.

\section{conclusion}

We found that the general quality of life average scores of the patients were good and receiving information about postoperative process, gender, marital status, and the post-transplantation period had a positive impacted the patients' quality of life, After transplantation, the agents which lower the quality of life can be determined. Health professionals can determine required strategies in order to improve life quality, and they may attempt for necessary efforts, because the individual whose life quality is high adapts to medical treatment well. In accordance with these results, it may be suggested that educational programs affecting the patients' quality of life should be organized, and that this study should be done in a wider context with patients who have undergone kidney transplants in different organizations. It is also suggested that the plans of nursing care should be prepared according to these findings.

\section{References}

1- CORESH H.J., SELVIN E., STEVEN L.A., et al.: Preva-lence of chronic kidney disease in the USA. The Journal of the American Medical Association (JAMA), 289: 2038- 2047, 2007.

2- MAHMOUD KH.M., SHEASHAA H.A., GHEITH O.A., WAFA E.W. and AGROUDY A.E.: Continuous ambulatory peritoneal dialysis in Egypt: Progression despite handicaps. Peritoneal Dialysis International J., 30: 269- 273, 2010.

3 -TONELLI M., WEIBEN N. and KNOLL G.: Kidney transplantation compared to dialysis in clinically relevant outcomes. A. J. of Transplantation, 11: 2093-2109, 2011.

4- DAVIS C.: Evaluation of living kidney donation: Current perspectives, Am. J. Kidney Disease, 43 (3): 508-530, 2004.

5- TALER S.J., MASSERMITH E.E. and GILLESPIE B.W.: Demographic, metabolic and blood pressure characteristics of living kidney donors spanning five decades. A. J. of Transplantation, 12 (11): Abstract, 2012.

6- MCPAKE D.: Caring for patients after kidney transplan-tation. Nursing Standard J., 23 (19): 49-57, 2008.

7- BITTENCOURT Z.C.Z., FILHO G.A., MAZZALIM M. and RODRIGUES N.: Quality of Life in renal transplan-tation: Impact of functional graft. Brazil: Rev,Sudpublica, 38.

8- Fujisawa M, Ichikawa $\mathrm{Y}$, Yoshiya $\mathrm{K}$, Isotani S, Higuchi A, Nagano S, et al. Assessment of health-related quality of life in renal transplant and hemodialysis patients using the sf-36 health survey. Urology. 2000;56(2):201-206.

9- Ogutmen B, Yildirim A, Sever MS, Bozfakioglu S, Ataman R, Erek, E, et al. Heath-related quality of life after kidney 
transplantation in comparison intermittent hemodialysis, peritoneal dialysis and normal controls. Transplant Proc. 2006;38(2):419-421.

10- Yildirim A. The Importance of patient satisfaction and health-related quality of life after renal transplantation. Transplant Proc. 2006;38(9):2831-2834.

11- Balaska A, Moustaffellos $P$, Gourgiotis S, Pistolas D, Hadjiyannaki E, Vaugas V, et al. Changes in health-related quality of life in Greek adult patients 1 year after successful renal transplantation. Exp Clin Transplant. 2006;4(2):521-524.

12- Curcani M, Tan M. The factors affecting the quality of life of patients who have undergone kidney transplants. Pak J Med Sci 2011;27(5):1092-1097.

13- Ustundag H, Gul A, Zengin N, Aydin M. Quality of Life in patient with renal transplantation. Firat Journal of Health Care. 2007;2:118-126.

14- Shu-Fen N, Li IC. Quality of life of patients having renal replacement therapy. J Adv Nurs. 2005;51(1):15-21.

15- Acaray, Pinar R. Assessment of quality of life in chronic hemodialysis patients. Cumhuriyet University J Nursery Academy 2004;8:1-11.

16- Akyol A, Karadakovan A. The investigation of influence factors on selfcare agency and quality of life on hemodialysis patients. Ege Med J. 2002;41(2):97-102.

17- Ponton P, Rupolo GP, Marchini F, Feltrin A, Perin N, Mazzoldi MA, et al. Quality of life change after kidney transplantation. Transplant Proc. 2001;33(1-2):1887-1889.

18- Chisholm MA, Spivey CA, Van Nus A. Influence of economic and demographic factors on quality of life in renal transplant recipients. Clin Transplant. 2007;21(2):285-293.

19- Chen WC, Chen CH, Lee PC, Wang WL. Quality of life, symptom distress, and social support among renal transplant recipients in southern Taiwan: A correlation study. J Nurs Res. 2007;15(4):319-329.graphic factors on quality of life in renal transplant recipients. Clin Transplant. 2007;21(2):285-293.

20 -Ozsaker E, Ozbayir T. The quality of life and related factors in kidney transplantation patients and patients' relatives. Ege University J Nursery Academy. 2005;21:247-252.

21- MOHAMMED A. FOUDA, M.D.*; AMANY M. Sh. ABD EL-LATIF, D.N.Sc.AMAL BAKR ABO EL-ATA, D.N.Sc.and SALHA S. RAMADAN, M.Sc. Med. J. Cairo Univ., Vol. 82, No. 2, March: 83-90, 2014.

22- OH C.K., LEE B.M., KIM H., KIM S.I. and KIM Y.S.: Predicting the ideal serum creatinine of kidney transplant recipients by a simple formula based on the balance between metabolic demands of recipients and renal mass supply from donors. Trans. Procedures J., 40 (7): 2307- 2309, 2008.

23- HURST F.P., BELUR P., NEE R. and AGODA L.N.: Poor outcomes associated with neutropenia after kidney transplantation. Transplantation, J., 92 (1):

$$
\text { 36-40, }
$$

2011. 